\title{
Occupations of fathers of children dying from neoplasms
}

\author{
B. M. SANDERS \\ From the Childhood Cancer Research Group, Department of Paediatrics, University of Oxford \\ G. C. WHITE \\ From the Division of Medical Statistics, Office of Population Censuses and Surveys, London
}

G. J. DRAPER

From the Childhood Cancer Research Group, Department of Paediatrics, University of Oxford

SUMMARY It has been suggested in a number of recent reports that there is a possible relationship between parental occupation and malignant disease in children. A proportional mortality analysis relating deaths among children in England and Wales in 1959-63 and 1970-72 to occupation of father as stated on the child's death certificate has not shown any convincing evidence for such associations. Earlier papers published on the subject are reviewed. Although there is some slight evidence for associations between childhood tumours and certain parental occupations there is little consistency between the results reported by different authors. A previously reported association between higher social class and deaths from neoplasms was found also in this study. The explanation for this finding is unknown, and it remains possible that it is an artefact.

Little is known about the causes of malignant disease in children although various studies have suggested that prenatal factors are responsible for some cases. Those factors include antenatal maternal $x$ rays, ${ }^{1}$ transplacental drug effects, ${ }^{2}$ and maternal virus infections during pregnancy, ${ }^{34}$ though the evidence for this is less convincing and contradictory results have been found in different studies. Some cases are associated with chromosome defects ${ }^{5}$ and some with genetic disease. ${ }^{6}$

In several reports the occurrence of childhood cancer has been considered in relation to parental occupation; these include four case-control studies, one from Canada, ${ }^{7}$ one from Finland, ${ }^{89}$ and two from the United States of America. ${ }^{10} 11$

Fabia and Thuy ${ }^{7}$ suggested that children of fathers in 'hydrocarbon-related occupations' might have an increased risk of malignant disease. In their study, 386 children under 5 dying of malignant disease were each matched with two controls born at about the same time, and the fathers' occupations, as recorded on birth certificates, were compared. Children born to fathers in 'hydrocarbon-related' occupations (defined as motor vehicle mechanics and service station attendants, machinists, miners and lumbermen, painters, dyers and cleaners) had approximately twice the risk of children of fathers in other occupations. The rationale for grouping occupations in this way is not clear from this paper, and in view of the rather mixed nature of the hydrocarbon-related group and the lack of specificity in the causes of death, it seems the findings may well have been due to chance.

Hakulinen $e^{a l^{8}}$ carried out a study of 852 children from the Finnish Cancer Registry. Each was matched with a control for date of birth and domicile. Fathers' occupations, as recorded when the mother. first attended an antenatal centre, were analysed. No excess risk of cancer was found among children whose fathers were in hydrocarbon-related occupations. Hemminki et $a l^{9}$ reanalysed these data together with a further 700 cases also from Finland. This analysis covered children diagnosed with cancer in Finland in two periods, $1959-68$ and 1969-75. A number of apparently increased risks were reported from various parental occupations.

The results reported included a small increased risk for children of fathers who were farmers and a relative risk of 1.9 for leukaemia in the period 1969-75 for children of fathers who were motor vehicle drivers. Increased risks were also reported for certain maternal occupations recorded at the time of pregnancy. However, in this study a large number of occupations were analysed, so that some statistically significant results would be expected to occur by chance.

Zack et al ${ }^{10}$ recorded parental occupations for 296 children with cancer attending the Texas Children's Hospital and compared these with occupations of (a) parents of patients without cancer, (b) siblings of the case parents, and (c) neighbours of the case parents. Information on job histories was collected 
for the period from a year before birth to a year before diagnosis. No association between hydrocarbon-related occupations and childhood neoplasms was found for either fathers or mothers.

In a study based on data from the Connecticut tumour registry Kantor et $\mathbf{l}^{11}$ reported an association between Wilms's tumour-a renal tumour of childhood-and paternal occupations 'related to lead'. Controls for 149 children with Wilms's tumour were matched for sex, race, and year of birth. The paternal occupations were obtained from children's birth certificates. Fathers classified as being in 'lead-related' occupations were drivers, motor vehicle mechanics, service station attendants, welders, solderers, metallurgists, and scrap metal workers: thus there is considerable overlap with the definition of 'hydrocarbon-related' occupations. However, it is important to notice that in Fabia and Thuy's paper none of the 71 tumours reported among children of fathers in hydrocarbon-related occupations was a Wilms's tumour, although 25 $(6.5 \%)$ of their total of 386 cases had this diagnosis. Nor was there any association between hydrocarbon-related occupations and Wilms's tumour in the report by Zack et al. ${ }^{10}$

There have also been two cohort studies of anaesthetists in which it has been suggested that their children may have an increased risk of developing cancer: Corbett et al ${ }^{12}$ reported three tumours (one at age 22) in two children out of 434 born to women anaesthetists; Tomlin ${ }^{13}$ reported tumours, at unspecified ages, in two children out of 276 whose fathers were anaesthetists. These numbers are greater than would be expected in the general population, but the published reports do not give sufficient information for the statistical significance of their findings to be assessed. It should be noted that the extent of the possible increase in risk is greatly exaggerated in the analysis presented in Tomlin's paper because the method of analysis used is incorrect-the effect being to multiply the estimated relative risk by an unknown factor which may well be 10 or more.

There appear to be no other published epidemiological studies on the relationship between parental occupation and childhood neoplasms.

We report in this paper an analysis of fathers' occupations, as recorded on death certificates, for all children dying in England and Wales during the years 1959-63 and 1970-72; the occupations of fathers of children dying from neoplasms are compared with those of children dying from other causes.

\section{Method}

For deaths among children under 15 in England and Wales the occupation of the father is routinely recorded on the child's death certificate. For all deaths in these countries occurring during the years 1959-63 and 1970-72 occupations were coded according to the United Kingdom Standard Classification of Occupations ${ }^{14} 15$ for use in the analyses of occupational mortality produced by the Registrar General. For children, the father's occupation was coded; these data were made available for the present analysis.

There are no population data giving numbers of children having fathers in each occupational group, so it is not possible to calculate childhood death rates related to father's occupation; instead we have used proportional mortality ratios (PMRs). The PMR for a specified cause of death and occupational group is defined in the present study as:

Proportion of deaths attributed to specified cause among children of fathers in the specified occupation

$100 \times$

Proportion of all childhood deaths attributed to the specified cause

Symbolically, if the total number of childhood deaths is $T$, and $C$ of these are attributed to a specified cause, while the number of deaths among children with fathers in a given occupational group is $t$, with $c$ being attributed to the specified cause,

$$
\begin{aligned}
\text { PMR } & =100 \times \frac{c}{t} \div \frac{C}{T} \\
& =\frac{100 c T}{t C}
\end{aligned}
$$

An association between the specified cause of death and paternal occupation will be reflected in a PMR greater than 100 . This can be tested for statistical significance by means of a $\chi^{2}$ test applied to the $2 \times 2$ table whose cell entries are $c, t-c, C-c$, $(\mathrm{T}-\mathrm{C})-(\mathrm{t}-\mathrm{c})$.

A positive association between a particular cause of death and an occupational group may be evidence of a causal relationship resulting from occupational exposure to some carcinogenic or mutagenic agent; on the other hand, as with any statistical relationship, the association may be indirect, and not causal, or it may simply be due to chance. In an analysis of PMRs there is an important potential source of false inferences which we have considered particularly carefully in the present analysis: since the method consists in calculating the proportions of fathers in a specified occupational group for certain causes of death, and comparing this with the proportion in that group for all causes of death, a spurious association could arise if there were an association between some of the remaining causes of death and some of the 
other occupations. In the particular case considered here, it is known that some non-neoplastic causes of childhood death are associated with lower social class and hence with certain parental occupations. In the analyses presented below we have therefore calculated PMRs by comparing numbers of deaths from neoplasms firstly with numbers of deaths from all causes and secondly with deaths from all causes excluding 'social-class-related' caüses.

The data consisted of numbers of childhood deaths under the age of 15 for each paternal occupation category. Deaths from neoplasms were subdivided into four groups, leukaemias, brain tumours, kidney tumours, other neoplasms. For the 1959-63 data only, the numbers of deaths from other causes were also subdivided according to the main headings of the International Classification of Diseases and by the child's age at death.

\section{Results}

In Table 1 we give PMRs for childhood deaths attributable to neoplasms for fathers within each broad occupation order defined in the Registrar General's classifications of occupations. ${ }^{14}{ }^{15}$ Most of the PMRs are fairly close to 100 and few of the figures show consistent deviations for the two periods. There are only three occupation orders, 22,
24, and 25 for which the PMRs were significantly high at the $5 \%$ level for each of the two periods. The PMRs for orders 3 and 21 were significant for the first period only. For reasons given below some at least of these findings may well be artefacts, and should not be taken as evidence of a direct association between these occupations and childhood cancer. The two most strikingly high PMRs are those for orders 24 and 25 , which consist mainly of occupations in Social Classes I and II. Some causes of death are known to be less common for children in these social classes and this could account, at least in part, for the high PMR for neoplasms. The converse argument could be applied, for instance, to the low value for occupation order 18 (labourers).

The occupation orders in Table 1 are of course heterogeneous, and even if the individual occupation units within each order are considered, it is not possible to produce sharply defined groups which can be classified as 'hydrocarbon-related'. In consultation with a specialist in occupational health, we have defined a group which includes miners, various workers in the engineering and allied trades, some textile workers, printing press operators, painters and decorators, dry cleaners and motor vehicle drivers. This is considered to be as close an approximation as is possible, within the Registrar General's classification of occupations, to a group of

Table 1 Proportional mortality ratios for deaths from neoplasms among children of fathers in each occupation order

\begin{tabular}{|c|c|c|c|c|c|c|c|}
\hline \multirow{2}{*}{\multicolumn{2}{|c|}{ Father's occupation order" }} & \multicolumn{3}{|l|}{$1959-1963$} & \multicolumn{3}{|l|}{$1970-1972$} \\
\hline & & $\begin{array}{l}\text { Deaths } \\
\text { from } \\
\text { neoplasms }\end{array}$ & $\begin{array}{l}\text { All } \\
\text { deaths }\end{array}$ & PMR & $\begin{array}{l}\text { Deaths } \\
\text { from } \\
\text { neoplasms }\end{array}$ & $\begin{array}{l}A l l \\
\text { deaths }\end{array}$ & $P M R$ \\
\hline $\begin{array}{l}1 \\
2 \\
3 \\
4 \\
5 \\
6 \\
7 \\
8 \\
9 \\
10 \\
11 \\
12 \\
13 \\
14 \\
15 \\
16 \\
17 \\
18 \\
19 \\
20 \\
21 \\
22 \\
23 \\
24 \\
25 \\
26 \\
27\end{array}$ & $\begin{array}{l}\text { Farmers } \\
\text { Miners } \\
\text { Gas, coke and chemical } \\
\text { Glass and ceramics } \\
\text { Furnace workers } \\
\text { Electrical } \\
\text { Engineering and allied trades } \\
\text { Woodworkers } \\
\text { Leather workers } \\
\text { Textile workers } \\
\text { Clothing workers } \\
\text { Food, drink and tobacco } \\
\text { Paper workers } \\
\text { Other products } \\
\text { Construction } \\
\text { Painters and decorators } \\
\text { Drivers of stationary engines, cranes, etc. } \\
\text { Labourers N.E.C. } \\
\text { Transport workers } \\
\text { Warehousemen } \\
\text { Clerical workers } \\
\text { Sales workers } \\
\text { Service, sport and recreation } \\
\text { Administrators and managers } \\
\text { Professional, technical workers, artists } \\
\text { Armed forces } \\
\text { Inadequately described, non-employed and others }\end{array}$ & $\begin{array}{r}188 \\
168 \\
58 \\
21 \\
72 \\
120 \\
656 \\
104 \\
15 \\
38 \\
15 \\
79 \\
54 \\
54 \\
171 \\
93 \\
92 \\
304 \\
429 \\
100 \\
252 \\
340 \\
177 \\
162 \\
393 \\
126 \\
114\end{array}$ & $\begin{array}{r}4420 \\
4611 \\
1045 \\
531 \\
1709 \\
3243 \\
16119 \\
2772 \\
442 \\
1039 \\
4475 \\
1686 \\
1167 \\
1180 \\
4379 \\
2472 \\
2216 \\
11714 \\
11904 \\
2392 \\
4375 \\
6633 \\
3977 \\
2295 \\
7139 \\
4469 \\
8436\end{array}$ & $\begin{array}{r}109 \\
94 \\
143 \\
102 \\
108 \\
95 \\
104 \\
96 \\
87 \\
94 \\
81 \\
120 \\
119 \\
117 \\
100 \\
97 \\
107 \\
67 \\
93 \\
107 \\
148 \\
132 \\
114 \\
181 \\
141 \\
72 \\
35\end{array}$ & $\begin{array}{r}86 \\
41 \\
21 \\
9 \\
36 \\
89 \\
391 \\
56 \\
5 \\
25 \\
11 \\
35 \\
29 \\
29 \\
107 \\
34 \\
40 \\
176 \\
252 \\
43 \\
124 \\
199 \\
115 \\
140 \\
294 \\
61 \\
77\end{array}$ & $\begin{array}{r}1540 \\
830 \\
525 \\
200 \\
697 \\
1808 \\
8828 \\
1293 \\
153 \\
722 \\
397 \\
850 \\
636 \\
695 \\
2462 \\
1002 \\
1036 \\
5066 \\
5166 \\
1257 \\
2388 \\
3411 \\
2480 \\
1 \quad 859 \\
4671 \\
1544 \\
3290\end{array}$ & $\begin{array}{r}121 \\
107 \\
87 \\
98 \\
112 \\
107 \\
96 \\
94 \\
71 \\
75 \\
60 \\
89 \\
99 \\
91 \\
94 \\
74 \\
84 \\
75 \\
106 \\
74 \\
113 \\
127 \\
101 \\
163 \\
137 \\
86 \\
51\end{array}$ \\
\hline \multicolumn{2}{|c|}{ TOTAL } & $\therefore 4395$ & 112840 & 100 & 2525 & 54806 & 100 \\
\hline
\end{tabular}

- Classifications of occupations'14 25 
workers with particularly high exposure to hydrocarbons (HCR group). We have used this to test the hypothesis suggested by Fabia and Thuy.

In Table 2 we give the PMRs for this group in the two periods under consideration; these are close to 100 and there is no suggestion here of any association with mortality from neoplasms. In order to compare the HCR group with a group more similar in social class composition we have also calculated PMRs using as a comparison group all other occupations excluding orders 24 and 25 . The PMRs resulting from this comparison are again very close to 100 .

In Table 3 we show the PMRs for separate diagnostic categories of neoplasm. It will be observed that in each period the PMR for deaths from kidney tumours was higher than that for all other neoplasms, though in neither period was it significantly different from 100. These raised PMRs are nevertheless of interest when we consider the findings of Kantor et al ${ }^{11}$ concerning 'lead-related' occupations. It is not possible within the Registrar General's classification of occupations to isolate a group of workers with particularly high exposure to lead but there is a considerable overlap with those occupations defined as 'hydrocarbon-related'. Within this latter group, the particularly high PMRs for deaths from kidney tumours were concentrated among the children of workers in 'engineering and allied trades'.

The calculation of PMRs for one cause of death can be misleading if death rates from other causes differ as between the groups of individuals being compared. For the 1959-63 data for which the information on causes of death for each occupation unit was available to us, we have therefore calculated PMRs after excluding 'social class-related' causes of death. These are defined here as infective, respiratory, diseases of early infancy and accidents. Table 4 gives the resulting PMRs for each age group and for all ages together.

These analyses do not suggest any association between deaths from neoplasms and HCR occupations either for the total group of cases or for separate age groups.

We have already commented on the high PMRs for occupation orders 24 and 25; a detailed analysis for these groups combined is presented in Table 5. For

Table 2 Proportional mortality ratios for deaths from neoplasms among children of fathers in hydrocarbon-related occupations

\begin{tabular}{llcccccr}
\hline & \multicolumn{3}{l}{ Deaths in 1959-63 } & \multicolumn{3}{c}{ Deaths in 1970-72 } \\
\cline { 2 - 7 } Occupations & Neoplasms : & All causes & PMR & Neoplasms & All causes & PMR \\
\hline Hydrocarbon-related & 1041 & 27784 & 96 & 523 & 12040 & 94 \\
All & 4395 & 112840 & 100 & 2525 & 54806 & 100 & \\
\hline
\end{tabular}

Table 3 Proportional mortality ratios for deaths from specified types of neoplasm among children of fathers in hydrocarbon-related occupations

\begin{tabular}{|c|c|c|c|c|c|c|c|c|c|}
\hline \multirow[b]{2}{*}{ Occupations } & \multicolumn{2}{|l|}{ Kidney } & \multicolumn{2}{|l|}{ Brain } & \multicolumn{2}{|c|}{ Leukaemia } & \multicolumn{2}{|c|}{ Other neoplasms } & \multirow[b]{2}{*}{ All deaths } \\
\hline & Deaths & $P M R$ & Deaths & $P M R$ & Deaths & PMR & Deaths & $P M R$ & \\
\hline $\begin{array}{l}1959-63 \\
\text { Hydrocarbon-related } \\
\text { All }\end{array}$ & $\begin{array}{r}79 \\
270\end{array}$ & 119 & $\begin{array}{r}260 \\
1161\end{array}$ & 91 & $\begin{array}{r}416 \\
1771\end{array}$ & $\begin{array}{l}95 \\
-\end{array}$ & $\begin{array}{r}286 \\
1193\end{array}$ & $\begin{array}{l}97 \\
-\end{array}$ & $\begin{array}{r}27784 \\
112840\end{array}$ \\
\hline $\begin{array}{l}1970-72 \\
\text { Hydrocarbon-related } \\
\text { All }\end{array}$ & $\begin{array}{r}32 \\
128\end{array}$ & 114 & $\begin{array}{l}159 \\
760\end{array}$ & 95 & $\begin{array}{r}202 \\
1000\end{array}$ & 92 & $\begin{array}{l}130 \\
637\end{array}$ & 93 & $\begin{array}{l}12040 \\
54806\end{array}$ \\
\hline
\end{tabular}

Table 4 Proportional mortality ratios for deaths from neoplasms at specified ages among children of fathers in hydrocarbon-related occupations (deaths in 1959-63 only)

\begin{tabular}{|c|c|c|c|c|c|c|c|c|c|c|c|c|c|c|c|}
\hline \multirow[b]{3}{*}{ Occupations } & \multicolumn{15}{|c|}{ Age groups (years) } \\
\hline & 0 & & & $1-4$ & & & $5-9$ & & & $10-14$ & & & All ages & & \\
\hline & $\begin{array}{l}\text { Neo- } \\
\text { plasm } \\
\text { deaths }\end{array}$ & $\begin{array}{l}\text { All } \\
\text { deaths }\end{array}$ & $P M R$ & $\begin{array}{l}\text { Neo- } \\
\text { plasm } \\
\text { deaths }\end{array}$ & $\begin{array}{l}\text { All } \\
\text { deaths }\end{array}$ & $P M R$ & $\begin{array}{l}\text { Neo- } \\
\text { plasm } \\
\text { deaths }\end{array}$ & $\begin{array}{l}\text { All } \\
\text { deaths }\end{array}$ & $P M R$ & $\begin{array}{l}\text { Neo- } \\
\text { plasm } \\
\text { deaths }\end{array}$ & $\begin{array}{l}\text { All } \\
\text { deaths }\end{array}$ & $P M R$ & $\begin{array}{l}\text { Neo- } \\
\text { plasm } \\
\text { deaths }\end{array}$ & $\begin{array}{l}\text { All } \\
\text { deaths }\end{array}$ & $P M R$ \\
\hline $\begin{array}{l}\text { Hydrocarbon- } \\
\text { related } \\
\text { All }\end{array}$ & $\begin{array}{r}95 \\
412\end{array}$ & $\begin{array}{r}6094 \\
24697\end{array}$ & $\begin{array}{r}93 \\
100\end{array}$ & $\begin{array}{r}382 \\
1569\end{array}$ & $\begin{array}{l}1521 \\
5993\end{array}$ & $\begin{array}{r}95 \\
100\end{array}$ & $\begin{array}{r}315 \\
1305\end{array}$ & $\begin{array}{r}784 \\
3290\end{array}$ & $\begin{array}{l}101 \\
100\end{array}$ & $\begin{array}{r}249 \\
1109\end{array}$ & $\begin{array}{r}728 \\
3144\end{array}$ & $\begin{array}{r}97 \\
100\end{array}$ & $\begin{array}{l}1041 \\
4395\end{array}$ & $\begin{array}{r}9127 \\
37124\end{array}$ & $\begin{array}{r}96 \\
100\end{array}$ \\
\hline
\end{tabular}

-Excluding deaths from social class-related causes. 
deaths in each period, and excluding those due to social class-related causes, the PMRs are given for separate diagnostic categories of neoplasm: for all of these the PMR is substantially greater than 100 . The PMRs for 'all neoplasms' are statistically very highly significant $(p<0.001)$ in each period.

Social class differences in mortality from childhood neoplasms have been reported by Adelstein and White, ${ }^{18}$ who used the data for 1959-63 reported here, and made a direct calculation of actual mortality rates for deaths at the ages of 1-14.

\section{Discussion}

The results presented above are largely negative but two findings are possibly of some interest in the light of previous reports.

Firstly, the apparent association between kidney tumours and 'hydrocarbon-related occupations' is in line with the findings of Kantor et al ${ }^{11}$ concerning Wilms's tumour and 'lead-related' occupations, and is biologically plausible, though it has not been confirmed in any other study.

Secondly, the apparently increased risk of cancer among children of parents in higher social classes has been previously reported. This may indicate a real difference in tumour incidence which is social class-related, but there is no obvious aetiological explanation (and other explanations are possible). Children in lower social classes may be more liable, when in a preclinical phase of cancer or leukaemia, to die from some other cause. Stewart and Kneale ${ }^{17}$ suggest an association between infection hazards and preleukaemia: lower incidence of infection and better medical care in the higher social classes would lessen the chance of dying from pneumonia or other infections. It is also possible that neoplasms are more likely to be misdiagnosed among children in lower social classes. Thus, even if the true incidence of neoplasms was equal in different social classes, the number of children diagnosed and dying from these causes might be fewer in lower social classes. Alternatively, the apparent excess of deaths from neoplasms among higher social classes may be attributable to a relative deficit of deaths from other causes even when the specified 'social class-related' deaths have been removed from the analysis, though this would not of course account for the findings of Adelstein and White. An examination of the total number of deaths from causes other than those which are 'social class-related' shows that more than half of them (20 931 out of 37124$)$ were attributed to congenital defects. Adelstein et $\mathbf{l}^{18}$ showed that for infant deaths from congenital defects from 1975-1977 there was indeed a social class gradient: children of fathers in Social Classes IV and V were about one-and-a-half times more likely to die from a congenital defect than those whose fathers were in Social Classes I and II. The same effect is indicated in a less marked way for children aged between 1 and 10 in the study by Adelstein and White ${ }^{16}$ of deaths between 1959 and 1963 . This would suggest that the findings of high PMRs for occupation groups 24 and 25 may be at least partly due to an artefact.

The present report differs from those previously published in that we have analysed occupations of the fathers as recorded on death registrations instead of those relating to the time of birth. If it is assumed that preconception events are relevant to the aetiology of childhood cancer, that is, that the postulated association may be the result of genetic damage, then the occupation at the time of the child's birth is the one of interest. If, on the other hand, the effect is assumed to be a postnatal one, then the occupation at the time of the child's death may in some cases be a better indication of the hazard.

Table 5 Proportional mortality ratios for deaths from specified types of neoplasm among children of fathers in professional and managerial occupations

\begin{tabular}{|c|c|c|c|c|c|c|c|c|c|c|c|}
\hline \multirow[b]{2}{*}{ Occupations } & \multicolumn{2}{|l|}{ Kidney } & \multicolumn{2}{|l|}{ Brain } & \multicolumn{2}{|c|}{ Leukaemia } & \multicolumn{2}{|c|}{$\begin{array}{l}\text { Other } \\
\text { neoplasms }\end{array}$} & \multicolumn{2}{|c|}{$\begin{array}{l}\text { All } \\
\text { neoplasms }\end{array}$} & \multirow[b]{2}{*}{-All deaths } \\
\hline & Deaths & $P M R$ & Deaths & $P M R$ & Deaths & $P M R$ & Deaths & $P M R$ & Deaths & $P M R$ & \\
\hline $\begin{array}{l}1959-63 \\
\text { Administrators and } \\
\text { managers; } \\
\text { professional, technical } \\
\text { workers, artists } \\
\text { All occupations }\end{array}$ & $\begin{array}{r}30 \\
270\end{array}$ & $\begin{array}{l}116 \\
100\end{array}$ & $\begin{array}{r}152 \\
1161\end{array}$ & $\begin{array}{l}137 \\
100\end{array}$ & $\begin{array}{r}239 \\
1771\end{array}$ & $\begin{array}{l}141 \\
100\end{array}$ & $\begin{array}{r}134 \\
1193\end{array}$ & $\begin{array}{l}117 \\
100\end{array}$ & $\begin{array}{r}555 \\
4395\end{array}$ & $\begin{array}{l}132 \\
100\end{array}$ & $\begin{array}{r}3557 \\
37124\end{array}$ \\
\hline $\begin{array}{l}1970-72 \\
\text { Administrators and } \\
\text { managers; } \\
\text { professional, technical } \\
\text { workers, artists } \\
\text { All occupations }\end{array}$ & $\begin{array}{r}19 \\
128\end{array}$ & $\begin{array}{l}108 \\
100\end{array}$ & $\begin{array}{l}136 \\
760\end{array}$ & $\begin{array}{l}130 \\
100\end{array}$ & $\begin{array}{r}169 \\
1000\end{array}$ & $\begin{array}{l}123 \\
100\end{array}$ & $\begin{array}{l}110 \\
637\end{array}$ & $\begin{array}{l}125 \\
100\end{array}$ & $\begin{array}{r}434 \\
2525\end{array}$ & $\begin{array}{l}125 \\
100\end{array}$ & $\begin{array}{r}2618 \\
18978\end{array}$ \\
\hline
\end{tabular}

- Excluding deaths from social class-related causes. 
The results presented here do not strongly support any of the previously suggested associations between childhood cancer and paternal occupations. Possible explanations are that the occupation recorded is the one at death, that occupations on death certificates are less precisely recorded than those used in some previous studies, and that the method of classification used here does not produce sharply defined occupational groups. Moreover, for reasons discussed above, the method of analysis, by proportional mortality ratios, may have obscured some relationships.

However, it should be remarked that the various earlier studies have not reported consistent relationships and it is reasonable to conclude that there is at present no unequivocally established association between any parental occupation and childhood cancer.

We thank Mr. D. J. Evans of the Safety Policy Division of the Health and Safety Executive for his help in compiling a group of occupations with particularly high exposure to hydrocarbons, $\mathrm{Dr}$. A. M. Adelstein for allowing us to analyse the data provided by the Office of Population Censuses and Surveys, and Mrs. E. M. Roberts for secretarial assistance.

Reprints from Dr. G. J. Draper, Childhood Cancer Research Group, Radcliffe Infirmary, Oxford OX2 $6 \mathrm{HE}$.

\section{References}

${ }^{1}$ Bithell JF, Stewart AM. Pre-natal irradiation and childhood malignancy: a review of British data from the Oxford Survey. Br J Cancer 1975; 31: 271-87.
${ }^{2}$ Herbst AL, Cole P, Colton T, Robboy SJ, Scully RE. Age-incidence and risk of diethylstilbestrol-related clear cell adenocarcinoma of the vagina and cervix. Am J Obstet Gynecol 1977; 128: 43-50.

${ }^{8}$ Fedrick $J$, Alberman ED. Reported influenza in pregnancy and subsequent cancer in the child. $\mathrm{Br} M e d \mathrm{~J}$ 1972; ii: 485-8.

${ }^{4}$ Munoz N. Perinatal viral infections and the risk of certain cancers. Prog Biochem Pharmacol 1978; 14: 104-8.

${ }^{5}$ Harnden DG. Cytogenics of human neoplasia. In: Mulvihill JJ, Miller RW, Fraumeni JR jr. Genetics of Human Cancer. New York: Raven Press, 1977: 87-104.

${ }^{6}$ Fraumeni JF jr. Clinical patterns of familial cancer. In: Mulvihill JJ, Miller RW, Fraumeni JF jr. Genetics of Human Cancer. New York: Raven Press, 1977: 223-34.

${ }^{7}$ Fabia T, Thuy TD. Occupation of father at time of birth of children dying of malignant diseases. Br J Prev Soc Med 1974; 28: 98-100.

${ }^{8}$ Hakulinen T, Salonen T, Teppo L. Cancer in the offspring of fathers in hydrocarbon-related occupations. Br J Prev Soc Med 1976; 30: 138-40.

${ }^{\circ}$ Hemminki K, Saloniemi I, Salonen T, Partanen T, Vainio H. Childhood cancer and parental occupation in Finland. J Epidemiol Community Health 1981; 35: 11-15.

${ }^{10}$ Zack M, Cannon S, Loyd D et al. Cancer in children of parents exposed to hydrocarbon-related industries and occupations. Am J Epidemiol 1980; 111: 329-36.

${ }^{11}$ Kantor AF, McCrea Curnen MG, Meigs JW, Flannery JT. Occupations of fathers of patients with Wilms's tumour. $J$ Epidemiol Community Health 1979; 33: 253-6.

${ }^{12}$ Corbett TH, Cornell RG, Endres JL, Lieding K. Birth defects among children of nurse-anesthetists. Anesthesiology 1974; 41: 341-4.

${ }^{13}$ Tomlin PJ. Health problems of anaesthetists and their families in the West Midlands. Br Med J 1979; i: $779-84$.

${ }^{14}$ Registrar General. Classification of Occupations (1960). London: HMSO, 1960.

${ }^{15}$ Office of Population Censuses and Surveys. Classification of Occupations (1970). London: HMSO, 1970.

${ }^{16}$ Adelstein AM, White GC. Causes of children's deaths analysed by social class. In: Child Health - a collection of studies. Studies on Medical and Population Subjects No. 31. London: HMSO, 1976: 23-40.

${ }^{17}$ Stewart A, Kneale GW. Role of local infections in the recognition of haemopoietic neoplasms. Nature 1969; 223: 741-2.

${ }^{18}$ Adelstein AM, Macdonald Davies IM, Weatherall JAC. Perinatal and infant mortality: social and biological factors 1975-77. Studies on Medical and Population Subjects. No. 41. London: HMSO, 1980: 102-4. 